\title{
Getting Unstuck with \\ Internationalization at Home: Seizing the Post-pandemic Moment
}

\author{
Madeleine Green
}

\section{An Uncertain Future for Higher Education and Internationalization}

As I write this essay in late May 2020, the higher education press is blanketed by debate about the enduring changes brought on by COVID-19. Some maintain that the pandemic has already triggered disruptive changes, such as the quick move to online learning and variations in the academic calendar. They speculate that these shifts will endure after the crisis passes. Others predict a shift in the landscape of higher education. In countries with a private higher education sector that is highly dependent on tuition revenue, a substantial number may close, and the resulting landscape will be dominated by stronger, richer institutions. One estimate is that $20 \%$ of private institutions in the United States will close (Wescott 2020).

Although changes precipitated by the pandemic have been largely reactive, many higher education observers see the crisis as presenting a window of opportunity for making lasting and fundamental changes long overdue in the academy. A minority view less visible in the press and undoubtedly less exciting and encouraging, highlights the inevitable pull of business as usual, that, over time, higher education will revert to old practices. Since it is not possible to predict the future, it is too early to know which scenario will dominate or if there will be some combination of the two.

The future of internationalization is equally contested. Some, such as Philip Altbach and Hans De Wit (2020), see the inevitable pull of returning to the status quo ante and are sceptical that the move to online learning will endure, that mobility will cease to be an important option over the long-term, or that institutions will easily give up the revenue provided by international students. Indeed, they speculate that institutions may double down on the recruitment of international students,

\footnotetext{
M. Green ( ()

International Association of Universities, Paris, France

e-mail: madeleinefgreen@gmail.com 
so important is the revenue they bring to the financial health (or viability) of the enterprise.

A major question is whether the pandemic will provide a moment for Internationalization at Home to flourish given that mobility, which already involves only the privileged few, will be curtailed for the foreseeable future. Will this disruption of the status quo push institutions to redirect their attention to the academic and socio-cultural benefits of internationalization, rather than the economic benefits, and pay serious attention to Internationalization at Home?

Although the past does not predict the future, it is useful to consider where internationalization was headed before the pandemic and the three important trends affecting the future of Internationalization at Home.

\section{Three Important Trends in Internationalization Pre-COVID}

Changing patterns of mobility: The last 20 years have seen tremendous growth in the numbers of international students, from 2.1 million in 2001 to 5.3 million in 2019 (IIE, Project Atlas), with China and India sending the lion's share of students. We have also seen a shift in the receiving nations, with the United States receiving a diminishing share of these students, from $28 \%$ in 2001 to $21 \%$ in 2019 (IIE, Project Atlas). Short-term credit mobility has grown, especially in the United States, where $64 \%$ of all students are engaged in education abroad programs of eight weeks or less (IIE, 2019, Open Doors.) But it is important to consider that patterns shift over time. Korea, Iran, and Saudi Arabia are no longer as significant senders as they were in the past. Government support for mobile students ebbs and flows. Intra-regional mobility has grown, and the attractiveness of the United States has waned while Canada and Australia have gained international enrolments. The result will certainly be less international mobility in the short-term, and perhaps long-term, as well as further shifts in the relative positions of sending and receiving countries.

The drive for revenue from international students: International students are a vital source of income for various nations and their institutions: Australia had 440,000 international students in higher education in 2018-19 (Australian Government Department of Education 2020). International education was Australia's fourth-largest export in 2019, worth nearly AU\$38 billion; about half of that total comes from higher education. (Australian Government Department of Education 2019). According to NAFSA estimates, international students bring US $\$ 41$ billion and 458,000 jobs to the U.S. economy (NAFSA n.d.). U.S. institutions compensated for the decrease in state appropriations after the 2008 recession by stepping up their recruitment of international students; international enrolments grew by 30 percent from 2007 to 2012. More than 36 percent of US campuses derive more than 10 percent of their income from international students (Fischer 2019). Many speculate that this financial dependency on international students in the high-receiving nations 
such as the U.S., Australia, and the U.K. is unsustainable and that the effect of the pandemic will cause a shift from seeing international students largely as a major revenue source to an earlier conception stressing the academic and socio-cultural benefits of their presence and a revival of "ethical internationalization" (De Wit 2020). A shift towards the original goals of internationalization would bode well for greater attention to Internationalization at Home.

The push for Internationalization at Home: International educators enthusiastically endorsed Internationalization at Home at the same time that mobility gained visibility and importance. If learning and the quality improvement of all aspects of higher education are key goals of internationalization, it stands to reason that nonmobile students and faculty need to participate as well. Internationalization at Home democratizes internationalization, broadening access to all students rather than the select few who have the financial means to be mobile. It represents an opportunity to incorporate global learning in the mainstream of curriculum, moving internationalization from the margins of an institution (where it generally resides) to the center. But Internationalization at Home has been an uphill battle, explained in part by the fact that mobility has been synonymous with internationalization and economic benefits have taken precedence over internationalization's academic and socio-cultural value. Although limited progress has been made to date, might a conscious move away from the "mobility equals internationalization" model, with the advantages of increased access, lower carbon footprint, and combatting brain drain, give new energy to Internationalization at Home? (White and Lee 2020).

\section{Moving Ahead with Internationalization at Home}

What will it take for Internationalization at Home to gain real traction in higher education? The jury is out on this question, as Leask and Green (2020) note, but doing more of the same is unlikely to yield anything but continued slow progress. As the following section of this essay outlines, several conditions will have to be present for this to happen.

\section{A Sense of Urgency}

Often, a sense of urgency is required to generate energy for important changes. Such pressure is usually a result of an external force or set of circumstances-budget crises, changes in government policy, and now COVID-19. The urgent issues resulting from the pandemic are practical and operational, such as coping with enrollment and revenue shortfalls and safely reopening campuses. Not surprisingly, curriculum (as opposed to pedagogy related to online instruction) is likely to take a back seat until the most pressing problems are tackled. Although the issues addressed by 
internationalization are of supreme urgency to humanity-climate change, poverty, health - to date, there has not been a sufficient sense of urgency on most campuses to warrant a sustained campaign for internationalization. This is not to say that some faculty members, often depending on their discipline, do not feel a sense of urgency about the global issues with which they are engaged. But given the competition for attention on any campus, the lack of success to date in truly embedding Internationalization at Home, and the overwhelming institutional preoccupation with coping with the immediate fallout of the pandemic, it is unlikely that Internationalization at Home will rise to the top of the priority list soon.

Is it possible to generate a sense of urgency without severe external pressure? It is not easy. An internally generated change such as Internationalization at Home usually starts with the perception that something is not working (a problem) or that it could be working a lot better (an opportunity). The more severe the perceived problem, the greater the likelihood of it generating a sense of urgency around its solution. Shared recognition of the existence of a problem and agreement on its nature constitutes a crucial first step, generally accomplished through abundant conversations among faculty, usually at the department level, or in the case of general education in the United States, with a larger group of faculties from many disciplines who teach in the general education program.

\section{Reframing the Discussion}

Another emerging theme in the internationalization discourse is that internationalization is not an end in itself. Rather, it is a means of furthering institutional and societal goals - enhancing the quality of teaching and research, fostering an educated citizenry, and solving local and world problems. Seen this way, internationalization is not just one more thing that faculty members are asked to do on top of everything else - and someone else's idea - but integral to their teaching and research. If internationalization is a means to an end, then the goals become more important than the means to accomplish it. Reframing the discussion in terms of goals should change the language of the discussion (allowing for a largely disciplinary lens and language), It should also diminish the dichotomy between Internationalization at Home and mobility; both can be seen as valid means to the achieve the same objectives, allowing for a "both and" rather than an "either or" approach. Any such mental shift is never easy, and making this happen will require subtle leadership by international officers and more visible leadership by faculty members.

\section{Leadership at Many Levels}

Enduring academic change requires strong faculty leadership as well as visible support and championing from the top. Putting greater emphasis on Internationalization 
at Home requires new thinking about what students need to learn and what goes on in the classroom. Administrative fiats may result in some level of compliance, but they rarely produce shifts in thinking or the belief that the new approach is anything but a fad. By the same token, changes supported by a few faculties rarely get enough traction to spread. They need to be encouraged by the support, resources, policy changes that administrators can provide. In short, an accelerated course for Internationalization at Home will require an articulate group of faculty leaders that is encouraged by vigorous institutional support.

\section{Collective and Individual Action}

The infamous silos of academe and the lack of collective ownership of the curriculum, sometimes even within academic departments, have resulted in a curriculum in many institutions that is not greater than the sum of its parts. Professors own their courses, and departments may or may not choose to provide a coherent study program to progress in such a way that students connect concepts from one course to another. Just as the fragmented curriculum is largely due to the lack of collective ownership, the inability to systematically integrate Internationalization at Home into the curriculum and campus life can be largely attributed to a lack of collective action. Internationalizing specific courses is certainly a good idea, but it will not ensure that students will gain global knowledge or intercultural skills throughout their studies. Similarly, a smattering of international research projects will enhance the quality of those particular efforts, but will likely not affect others.

The curricular and extra-curricular changes required by Internationalization at Home will require collective examination of current curriculum and campus life, developing a shared sense of goals and direction, and agreement on a shared course of action that provides broad commonalities and at the same time allows each faculty member and administrator to autonomously achieve those goals.

\section{A Positive Agenda}

The loftier goals of internationalization should resonate, especially today. Institutions need to be - and be seen as - beacons of progress and hope in a world roiled by COVID19, perilous inequality, and growing nationalism and xenophobia. The pandemic represents an opportunity for institutions and their faculty and administrators to make a strong statement to students and the public about their values and their contributions to society. This is an agenda that has the potential of rallying wide support within the academy and providing a foundation for concerted action. 


\section{Conclusion}

While COVID-19 may present a window of opportunity for Internationalization at Home, without a new sense of urgency, a new language, sense of purpose, and commitment and leadership at many institutional levels, it is likely to progress at a very slow pace and remain a low priority for HEIs. Internationalization at Home is an ambitious change. One requiring many faculty members to think differently about their disciplines and courses, and for administrators to develop a different frame of reference for the workings of the institutions. The challenge is great, but the opportunity is there to seize.

\section{References}

Altbach, P., \& De Wit, H. ( 2020, March 14). COVID-19: The Internationalisation Revolution that Isn't. University World News. Retrieved from: https://www.universityworldnews.com/post.php? story $=20200312143728370(26.07 .2020)$

Australian Government Department of Education (2019, December). Research Snapshot. Retrived from: https://internationaleducation.gov.au/research/Research-Snapshots/Documents/ Education\%20infographic\%20Australia\%202018--19.pdf (26.07.2020)

Australian Government Department of Education. (2020, January). Research Snapshot. Retrieved from: https://internationaleducation.gov.au/research/Research-Snapshots/Documents/ RS_AusUKComparison.pdf (26.07.2020)

De Wit, H. ( 2020, May 23). Business Model of Internationalisation is Falling Apart. University World News. Retrieved from: https://www.universityworldnews.com/post.php? story $=20200519133420380(26.07 .2020)$

Fischer, K. ( 2019, September 13). International students bailed out colleges in the last recession. They won't this time. Chronicle of Higher Education. Retrieved from: https://www.chronicle. com/article/International-Students-Bailed/2471 30 (26.07.2020)

Institute for International Education (IIE). (2019). Project Atlas. Retrieved from: https://www.iie. org/en/Research-and-Insights/Project-Atlas/Explore-Data/Infographics/2019-Project-AtlasInfographics (26.07.2020)

Institute for International Education (IIE). (2019). Open Doors Fast Facts. Retrieved from: https://www.iie.org/Research-and-Insights/Open-Doors/Fact-Sheets-and-Infographics/FastFacts (26.07.2020)

Leask, B., \& Green, W. (2020, May 02). Is the Pandemic a Watershed for Internationalisation? University World News. Retrieved from: https://www.universityworldnews.com/post.php? story $=20200501141641136(26.07 .2020)$

NAFSA (n.d.). NAFSA International Student Economic Value Tool. Retrieved from: https://www. nafsa.org/policy-and-advocacy/policy-resources/nafsa-international-student-economic-valuetool-v2 (26.07.2020)

Wescott, D. ( 2020, March 25). Will the Corona Virus Close Your College for Good? Chronicle of Higher Education. Retrieved from: https://www.chronicle.com/article/Will-Coronavirus-CloseYour/248331 (26.07.2020)

White, B., \& Lee, J. ( 2020, April 18). The Future of international HE in a post-mobility world. University World News. Retrieved from: https://www.universityworldnews.com/post.php? story $=20200417105255362(26.07 .2020)$ 
Madeleine Green served as Vice President for International Initiatives at the American Council on Education until 2010. Since then, she has served as a Senior Fellow at NAFSA: the Association of International Educators and as an independent consultant. Her principal areas of expertise are policy and practice in internationalization and institutional leadership, management and governance. She is widely published in these areas. She has served as a member of the IAU administrative board and on the boards of several U.S. higher education institutions and organizations. She is Senior Fellow of the IAU.

Open Access This chapter is licensed under the terms of the Creative Commons Attribution 4.0 International License (http://creativecommons.org/licenses/by/4.0/), which permits use, sharing, adaptation, distribution and reproduction in any medium or format, as long as you give appropriate credit to the original author(s) and the source, provide a link to the Creative Commons license and indicate if changes were made.

The images or other third party material in this chapter are included in the chapter's Creative Commons license, unless indicated otherwise in a credit line to the material. If material is not included in the chapter's Creative Commons license and your intended use is not permitted by statutory regulation or exceeds the permitted use, you will need to obtain permission directly from the copyright holder. 